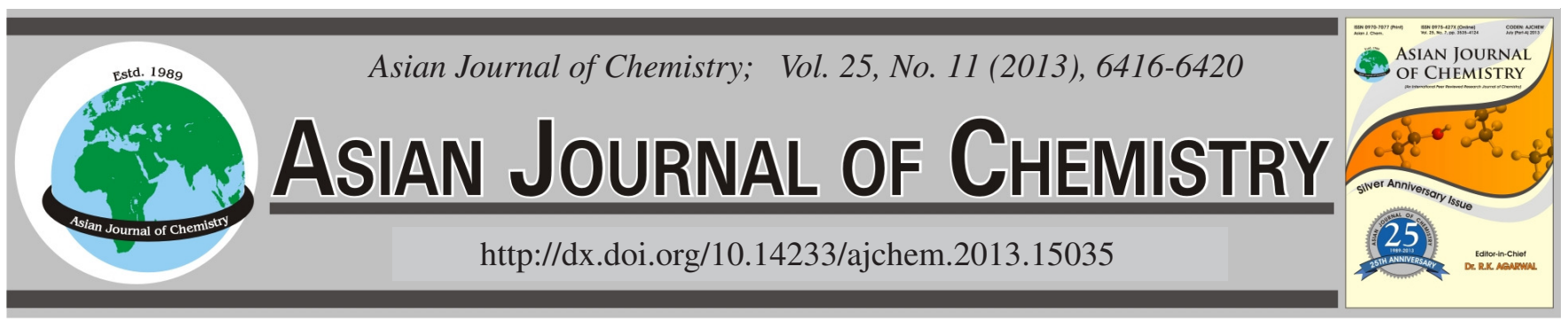

\title{
Cationic-Enhanced Spectrofluorimetric Method for Determination of Selective Serotonin Reuptake Inhibitor Duloxetine Hydrochloride in its Dosage Forms
}

\author{
Nawal A. Alarfaj ${ }^{1, *}$, Reda A. Ammar ${ }^{1,2}$ and Maha F. El-Tohamy ${ }^{1}$
}

${ }^{1}$ Department of Chemistry, College of Science, King Saud University, P.O. Box 22452, Riyadh 11495, Saudi Arabia

${ }^{2}$ Department of Chemistry, College of Science, Al-Azhar University, Cairo, Egypt

*Corresponding author: E-mail: nalarfaj@hotmail.com

(Received: 26 December 2012;

Accepted: 11 May 2013)

AJC-13484

A highly sensitive, rapid, accurate and precise spectrofluorimetric method was developed for the determination of duloxetine hydrochlo-
ride in its pharmaceutical formulations. The proposed method is based on investigation of the fluorescence spectral behaviour of duloxetine
hydrochloride in cetyl trimethylammonium bromide $(\mathrm{CTAB})$ micellar system. In aqueous solution of borate buffer $\mathrm{pH} 9.9$, the fluores-
cence intensity of duloxetine hydrochloride was greatly enhanced, 3-fold enhancement, in the presence of cetyl trimethylammonium
bromide. The fluorescence intensity of duloxetine hydrochloride was measured at $382 \mathrm{~nm}$ after excitation at $275 \mathrm{~nm}$. The fluorescence-
concentration plot was rectilinear over the range of $1-70 \mathrm{ng} / \mathrm{mL}$ with lower detection limit of $0.5 \mathrm{ng} / \mathrm{mL}$. The method was successfully
applied to the analysis of duloxetine hydrochloride in its commercial dosage forms. The results were in good agreement with those
obtained with the reported method. The application of the proposed method was extended to the stability studies of duloxetine hydrochloride
after exposure to different forced degradation conditions, such as acidic, alkaline, oxidative and thermal conditions, according to ICH guidelines.

Key Words: Cationic surfactant, Spectrofluorimetry, Duloxetine hydrochloride, Cetyltrimethylammoium bromide.

\section{INTRODUCTION}

Duloxetine hydrochloride is chemically, $N$-methyl-3napthalen-1-oxy-3-thiophen-2-yl-1-amine ${ }^{1}$. Duloxetine hydrochloride (Fig. 1) is a new selective serotonin and norepinephrine reuptake inhibitor used for major depressive disorders ${ }^{2}$. It is also indicated for the management of neuropathic pain associated with diabetic peripheral neuropathy ${ }^{3}$. Duloxetine hydrochloride is considered among the most important antidepressant drugs therefore, the development of reliable rapid and accurate procedures for this active ingredient quantification is welcomed. Several analytical methods have been reported for determination of duloxetine hydrochloride in its pure form, pharmaceutical preparations and biological fluids, where duloxetine hydrochloride is determined officially in any pharmacopoeia. These methods include high-performance liquid chromatography ${ }^{4-6}$, liquid chromatography coupled with mass spectrometry ${ }^{7-9}$, high performance thin layer chromatography $^{10}$, spectrophotometry ${ }^{11}$, capillary zone electrophoresis ${ }^{12}$, screen printed potentiomerty ${ }^{13}$ and spectrofluorimetry ${ }^{14}$. The reported spectrofluorometric method ${ }^{14}$ is based on the investigation of native fluorescence of duloxetine hydrochloride in a concentration range $0.02-0.4 \mu \mathrm{g} / \mathrm{mL}$ in $0.05 \mathrm{~mol} / \mathrm{L}$ acetic acid having excitation at $225 \mathrm{~nm}$ and emission at $340 \mathrm{~nm}$. Although, the previous reported methods are very sensitive, they are not adapted for in situ and real time detection of duloxetine hydrochloride as they are time consuming or involve expensive apparatus or require skilled technicians.<smiles>CNCC[C@H](Oc1cccc2ccccc12)c1cccs1</smiles>

Fig. 1. Chemical structure of duloxetine hydrochloride

Spectrofluorimetry is considered more convenient alternative analytical technique because of its inherent simplicity, easily operated and economic. The main goal of the present study is to investigate the native fluorescence characteristics of duloxetine hydrochloride in aqueous medium and in cetyl trimethylammoium bromide (CTAB) micellar medium. Based on the micellar-enhancement effect of CTAB on the native fluorescence intensity of duloxetine hydrochloride, a simple and highly sensitive spectrofluorimetric method has been 
developed for the determination of duloxetine hydrochloride in capsules. The stability-indicating capability of the proposed spectrofluorimetric method was evaluated through forced degradation studies of duloxetine hydrochloride drug under various degradation conditions according to $\mathrm{ICH}$ guidelines ${ }^{15}$.

\section{EXPERIMENTAL}

The fluorescence intensity was measured on a Perkin-Elmer model LS-55 luminescence spectrometer (UK), equipped with a $150 \mathrm{~W}$ xenon arc lamp, grating excitation and emission monochromators and a Perkin-Elmer recorder. Slit widths for excitation and emission monochromators were set at $5 \mathrm{~nm}$ for both excitation and emission. A $1 \mathrm{~cm}$ quartz cell was used. HANNA $\mathrm{pH}$ meter (Romania) was used for $\mathrm{pH}$ adjustments.

All reagents were of analytical grade and distilled water was used throughout the work. Pure grade duloxetine hydrochloride was kindly supplied from Jean Radne Sale (India). The pharmaceutical preparation (Cymbalta ${ }^{\circledR} 60 \mathrm{mg} / \mathrm{capsule}$, Lily S.A. Spain) was purchased from local drug stores. Sodium dodecyl sulphate (SDS, $95 \%$ ), cetyl trimethylammonium bromide (CTAB, $99 \%$ ), Tween 80, Triton X-100, Glycerol, sodium acetate trihydrate, boric acid and sodium hydroxide were purchased from Winlab (UK). Methanol (99.5\%), ethanol $(96.0 \%)$ and $n$-propanol $(99.5 \%)$ were obtained from Sigma-Aldrich (Germany). Acetonitrile was obtained from Merck (Germany). Dimethyl sulfoxide, dimethyl formamide, glacial acetic acid and hydrochloric acid were purchased from BDH laboratory supplies (England).

Standard solution: Stock solution of duloxetine hydrochloride was prepared by dissolving $10 \mathrm{mg}$ of the drug in 100 $\mathrm{mL}$ of distilled water. Further dilutions ranging from (1-70 $\mathrm{ng} / \mathrm{mL}$ ) were done with the same solvent as appropriate. The standard solution was stable for 10 days when kept in the refrigerator.

Procedure for calibration graph: A serial dilution covering the concentration range $1-70 \mathrm{ng} / \mathrm{mL}$ of the drug standard solution was done and transferred into a series of 10 $\mathrm{mL}$ volumetric flasks. Then $1 \mathrm{~mL}$ of $0.1 \mathrm{~mol} / \mathrm{L}$ borate buffer solution of $\mathrm{pH} 9.9$ was added to each flask followed by $1 \mathrm{~mL}$ of $2 \% \mathrm{w} / \mathrm{v}$ CTAB, mixed well and the fluorescence intensity was measured at $382 \mathrm{~nm}$ after excitation at $275 \mathrm{~nm}$. The fluorescence intensity was plotted $v s$. the final drug concentrations $(\mathrm{ng} / \mathrm{mL})$ to get the calibration graph. Alternatively, the corresponding regression equation was derived.

Procedure for capsules: The total content of 10 capsules was mixed well. A weighed quantity of the powder equivalent to $10 \mathrm{mg}$ of duloxetine hydrochloride was transferred into a $100 \mathrm{~mL}$ volumetric flask, about $80 \mathrm{~mL}$ of distilled water was added and the flask was sonicated for $10 \mathrm{~min}$. The solution was diluted to volume with distilled water, mixed and filtered. Serial dilutions covering the working concentration range of 1-70 ng/mL were transferred into $10 \mathrm{~mL}$ volumetric flasks. Procedure described above was then performed. The nominal content of the capsules was calculated using the calibration graph or the corresponding regression equation.

\section{Procedure for stability study}

Acid and base induced degradation studies: A small amount of duloxetine hydrochloride stock solutions (equiva- lent to $100 \mu \mathrm{g}$ of the drug) were transferred into a series of small conical flasks as previously reported ${ }^{10}, 10 \mathrm{~mL}$ of 0.5 $\mathrm{mol} / \mathrm{L}$ hydrochloric acid was added at room temperature for 4 $\mathrm{h}$. The studies under alkaline conditions were carried out using $10 \mathrm{~mL}$ of $2 \mathrm{~mol} / \mathrm{L}$ sodium hydroxide at room temperature for 8 h. $1 \mathrm{~mL}$ of resulting solution was then transferred into a 10 $\mathrm{mL}$ volumetric flask and procedure described above was then followed.

Oxidative degradation: Aliquots of duloxetine hydrochloride stock solution (equivalent to $100 \mu \mathrm{g}$ of the drug) were transferred into a series of small volumetric flasks; $10 \mathrm{~mL}$ of $30 \% \mathrm{H}_{2} \mathrm{O}_{2}$ were added and each volume was completed with distilled water. $1 \mathrm{~mL}$ of each solution was transferred into a $10 \mathrm{~mL}$ volumetric flask and procedure described above was then followed.

Thermal degradation: Aliquots of duloxetine hydrochloride stock solution (containing $100 \mu \mathrm{g}$ of the drug) were transferred into a series of 10-mL volumetric flasks; completed to volume with distilled water. The thermal degradation of the drug was carried out by heating at $70^{\circ} \mathrm{C}$ for $5 \mathrm{~h} .1 \mathrm{~mL}$ of each solution was transferred into a $10 \mathrm{~mL}$ volumetric flask then following the procedure for calibration graph.

\section{RESULTS AND DISCUSSION}

Duloxetine hydrochloride was found to exhibit an emission band at $382 \mathrm{~nm}$ in aqueous borate buffer of $\mathrm{pH} 9.9$, after excitation at $275 \mathrm{~nm}$. It was aimed to enhance this emission band, attempting to explore a new sensitive methodology for the analysis of duloxetine hydrochloride in its pharmaceutical preparations. It is well known that the addition of a surfactant at a concentration above its critical micellar concentration to a given fluorophore solution increases the molar absorbitivity and/or the fluorescence quantum yield of the fluorophore in many cases ${ }^{16}$. This fact has been used to improve the performance of spectrofluorimetric methods of various analytes. The fluorescence properties of duloxetine hydrochloride in various micellar media were studied, there was an enhancement of the fluorescence intensity in presence of CTAB compared with aqueous solution (about 3 fold enhancement) and so that CTAB was used as a fluorescence enhancer in order to develop a new spectrofluorimetric method for the determination of duloxetine hydrochloride.

\section{Optimization of experimental conditions}

Fluorescence spectra of duloxetine hydrochloride in aqueous and CTAB systems: The fluorescence spectra of duloxetine hydrochloride in both aqueous and CTAB systems were studied. Fig. 2, illustrates the obtained fluorescence spectra of duloxetine hydrochloride in the two systems. One of them was aqueous borate buffer of $\mathrm{pH} 9.9$, while the second one was the same borate buffer in presence of CTAB as a fluorescence enhancer. The percentage of fluorescence enhancement in presence of CTAB was about 3-fold enhancement compared with the native fluorescence intensity of the drug in buffer aqueous medium.

Effect of surfactants: The fluorescence properties of duloxetine hydrochloride in various micellar media were studied using cationic surfactant (CTAB), anionic surfactant sodium dodecyle sulphate (SDS) and non ionic surfactant 


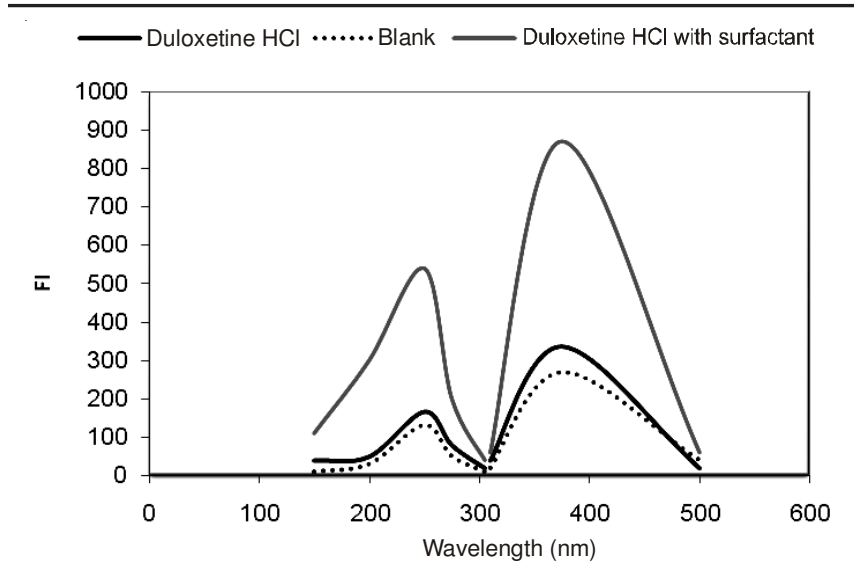

Fig. 2. Spectra of $1 \mathrm{ng} / \mathrm{mL}$ duloxetine hydrochloride

(Tween-80, Triton-100 and Glycerol). All the studied organized media caused decrease in native fluorescence of duloxetine hydrochloride or even have no significant effect on its fluorescence intensity, while CTAB system gave a substantial enhancement effect on the fluorescence intensity of duloxetine hydrochloride solution (Fig. 3).

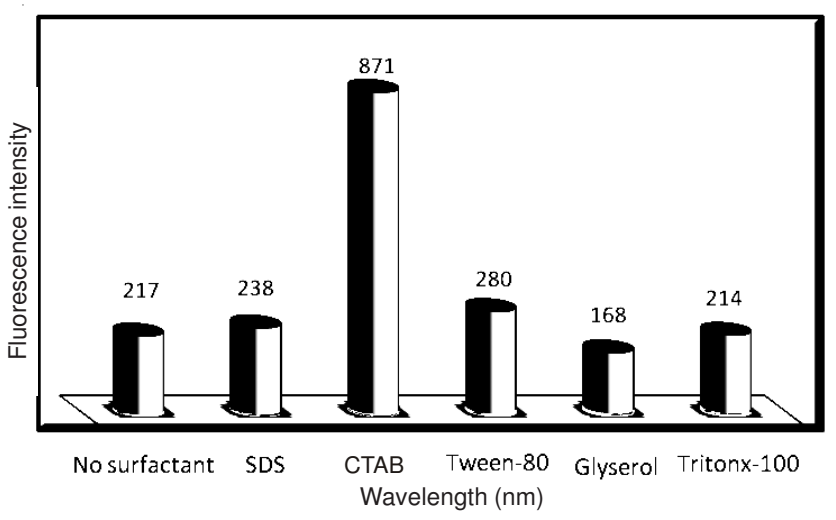

Fig. 3. Effect of type of surfactant ( $1 \mathrm{~mL}$ of $2 \%$ solution of each surfactant) on fluorescence intensity of duloxetine hydrochloride $(1 \mathrm{ng} / \mathrm{mL})$

Effect of CTAB volume: The influence of CTAB on the fluorescence intensity was studied using increasing volumes of $2 \%(\mathrm{w} / \mathrm{v})$ of CTAB. It was found that increasing volumes of CTAB in $10 \mathrm{~mL}$ volumetric flasks solution resulted in corresponding increase in fluorescence intensity up to $1 \mathrm{~mL}$, after which no further increase in fluorescence intensity was attained. Therefore, $1 \mathrm{~mL}$ of CTAB was chosen as the optimum volume for duloxetine hydrochloride determination (Fig. 4).

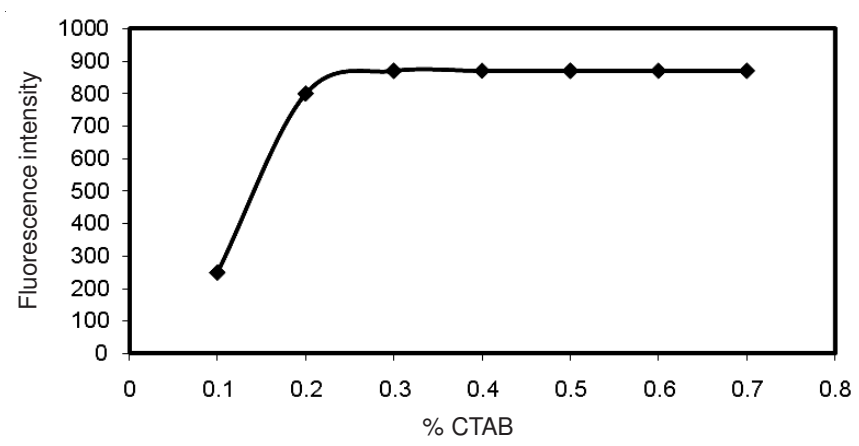

Fig. 4. Effect of volume of $2 \%$ CTAB on fluorescence intensity of duloxetine hydrochloride $(1 \mathrm{ng} / \mathrm{mL})$
Effect of pH: The influence of $\mathrm{pH}$ on the micelleenhanced fluorescence of duloxetine hydrochloride can be observed in Fig. 5. Different types of buffer solutions covering the whole $\mathrm{pH}$ range, such as $0.2 \mathrm{~mol} / \mathrm{L}$ acetate buffer over the $\mathrm{pH}$ range of 3.5-5.6, $0.2 \mathrm{~mol} / \mathrm{L}$ phosphate buffer over $\mathrm{pH}$ range 5.6-8.3 and $0.1 \mathrm{~mol} / \mathrm{L}$ borate buffer ranging from $\mathrm{pH}$ 8.3-12.3. It was found that maximum fluorescence intensity was achieved at $\mathrm{pH}$ 9.9-11 for duloxetine hydrochloride drug, so that, $\mathrm{pH} 9.9$ was chosen as the optimum $\mathrm{pH}$ value.

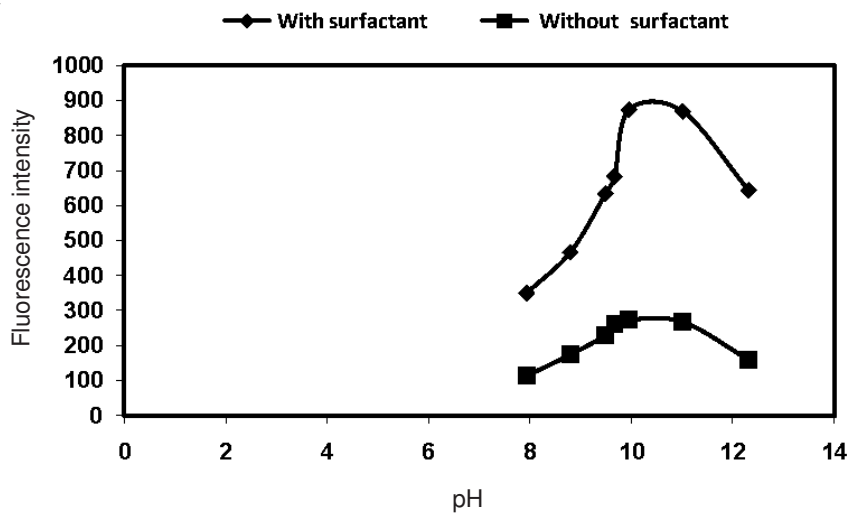

Fig. 5. Effect of $\mathrm{pH}$ on fluorescence intensity of duloxetine hydrochloride $(1 \mathrm{ng} / \mathrm{mL})$ in presence of $2 \%$ CTAB and in aqueous medium

Effect of diluting solvent: The effect of different diluting solvents for drug working solution on fluorescence intensity of duloxetine hydrochloride in presence of CTAB was investigated using water, methanol, acetonitrile, $n$-propanol, dimethyl sulfoxide and dimethyl formamide. It was found that water was the best solvent for dilution as it gave the highest fluorescence intensity. Distinct and sharp increase in the fluorescence intensities was observed in CTAB system upon using methanol, acetonitrile or $n$-propanol. This effect was attributed to their denaturating effect on the micelles, where, short-chain alcohols (methanol and $n$-propanol) were solubilizied mainly in the aqueous phase and affect the micellization process by modifying the solvent properties. Addition of these alcohols also results in reduction of size of the micelles, but with a progressive breakdown of the surfactant aggregate at very high concentrations ${ }^{17}$. Each of dimethyl sulfoxide and dimethyl formamide decreased the fluorescence intensity of duloxetine hydrochloride, since they initiated intersystem crossing process (similar to heavy atom effect) ${ }^{18}$.

Effect of time: The effect of time on the fluorescence intensity of the studied drug was also studied. It was found that the fluorescence intensity was immediately developed and remained stable for more than $1 \mathrm{~h}$.

\section{Method validation}

Linearity: Under the described experimental conditions, linearity for the micelle enhanced fluorescence system, was evaluated by analyzing a series of six standard solutions (three replicates for each one) of duloxetine hydrochloride and measured by following the procedure described in the experimental section. Table-1, resumed the results obtained from statistical analysis of data obtained. The calibration graph of fluorescence intensity $v s$. duloxetine hydrochloride concentration expressed in $\mathrm{ng} / \mathrm{mL}$ was found to be linear in the range of $1-70 \mathrm{ng} / \mathrm{mL}$. 


\begin{tabular}{lc}
\hline \multicolumn{2}{c}{ TABLE-1 } \\
PERFORMANCE DATA FOR THE PROPOSED \\
\multicolumn{2}{c}{ SPECTROFLUORIMETRIC DETERMINATION OF } \\
DULOXETINE HYDROCHLORIDE \\
\hline Parameter & Value \\
\hline Concentration range $(\mathrm{ng} / \mathrm{mL})$ & $1.0-70.0$ \\
Limit of detection (LOD) $(\mathrm{ng} / \mathrm{mL})$ & 0.5 \\
Limit of quantification $(\mathrm{LOQ})(\mathrm{ng} / \mathrm{mL})$ & 1.0 \\
Correlation coefficient $(\mathrm{r})$ & 0.9998 \\
Slope & 61.43 \\
Intercept & 96.67 \\
RSD $(\%)$ & 0.23 \\
Error* $(\%)$ & 0.88 \\
\hline$* \%$ Error $=\mathrm{SD} / \sqrt{ } \mathrm{n}$ & \\
&
\end{tabular}

Limit of quantification and limit of detection: The limit of quantification was determined by establishing the lowest concentration that can be measured according to ICH Q2 (R1) recommendation ${ }^{15}$ below which the calibration graph is non linear. The limit of detection was determined by evaluating the lowest concentration of the analyte that can be readily detected. The results were summarized in Table-1.

Accuracy and precision: Statistical analysis ${ }^{15}$ of the results obtained by the proposed and a reported spectrophotometric method $^{11}$ (which includes the determination of duloxetine hydrochloride in $0.1 \mathrm{~mol} / \mathrm{L} \mathrm{HCl}$ at $288 \mathrm{~nm}$ ) using student's $t$-test and variance ratio $F$-test showed no significant differences between the two methods regarding accuracy and precision, respectively, (Table-2). The intra-day precision was evaluated by determination of three concentrations of duloxetine hydrochloride drug in pure form on three successive occasions. The inter-day precision was also evaluated through replicate analysis of three concentrations for a period of 3 successive days. The results of intra-day and inter-day precision are summarized in Table-3.

\begin{tabular}{|c|c|c|c|c|c|c|}
\hline \multicolumn{7}{|c|}{$\begin{array}{c}\text { TABLE- } 2 \\
\text { APPLICATION OF THE PROPOSED AND COMPARISON } \\
\text { METHODS TO THE DETERMINATION OF DULOXETINE } \\
\text { HYDROCHLORIDE IN PURE FORM AND IN } \\
\text { PHARMACEUTICAL DOSAGE FORM }\end{array}$} \\
\hline \multicolumn{7}{|c|}{ Duloxetine hydrochloride } \\
\hline \multicolumn{4}{|c|}{ Proposed method } & \multicolumn{3}{|c|}{ Reported method $^{11}$} \\
\hline & \begin{tabular}{|c|} 
Taken \\
$(\mathrm{ng} / \mathrm{mL})$
\end{tabular} & $\begin{array}{c}\text { Found } \\
(\mathrm{ng} / \mathrm{mL})\end{array}$ & $\begin{array}{c}\text { Found } \\
(\%)\end{array}$ & $\begin{array}{c}\text { Taken } \\
(\mathrm{ng} / \mathrm{mL})\end{array}$ & $\begin{array}{c}\text { Found } \\
(\mathrm{ng} / \mathrm{mL})\end{array}$ & $\begin{array}{c}\text { Found } \\
(\%)\end{array}$ \\
\hline \multirow[t]{6}{*}{ Pure form } & 2 & 1.96 & 98.00 & 2 & 1.99 & 99.50 \\
\hline & 6 & 5.96 & 99.33 & 6 & 5.98 & 99.67 \\
\hline & 10 & 9.97 & 99.70 & 10 & 9.94 & 99.40 \\
\hline & 20 & 19.95 & 99.75 & 20 & 20.01 & 100.05 \\
\hline & 50 & 49.96 & 99.92 & 50 & 49.94 & 99.88 \\
\hline & 70 & 69.94 & 99.91 & 70 & 70.00 & 100.00 \\
\hline \multirow[t]{2}{*}{$\begin{array}{c}\text { Mean } \pm \text { SD } \\
t \text {-Test } \\
F \text {-test }\end{array}$} & \multicolumn{3}{|c|}{$\begin{array}{l}99.44 \pm 0.73 \\
0.97(2.23)^{*} \\
4.91(5.05)^{*}\end{array}$} & \multicolumn{3}{|c|}{$99.75 \pm 0.27$} \\
\hline & \begin{tabular}{|c|} 
Taken \\
$(\mathrm{ng} / \mathrm{mL})$
\end{tabular} & $\begin{array}{l}\text { Found } \\
(\mathrm{ng} / \mathrm{mL})\end{array}$ & $\begin{array}{c}\text { Found } \\
(\%)\end{array}$ & $\begin{array}{c}\text { Taken } \\
(\mathrm{ng} / \mathrm{mL})\end{array}$ & $\begin{array}{c}\text { Found } \\
(\mathrm{ng} / \mathrm{mL})\end{array}$ & $\begin{array}{c}\text { Found } \\
(\%)\end{array}$ \\
\hline \multirow{6}{*}{$\begin{array}{c}\text { Cymbalta }^{\circledR} \\
60 \\
\text { mg/Capsule }\end{array}$} & 5 & 5.01 & 100.20 & 5 & 4.95 & 99.00 \\
\hline & 8 & 7.99 & 99.87 & 8 & 7.99 & 99.87 \\
\hline & 10 & 9.78 & 97.80 & 10 & 10.02 & 100.20 \\
\hline & 20 & 19.96 & 99.80 & 20 & 19.87 & 99.35 \\
\hline & 50 & 49.89 & 99.78 & 50 & 49.85 & 99.70 \\
\hline & 70 & 69.93 & 99.90 & 70 & 70.00 & 100.00 \\
\hline $\begin{array}{c}\text { Mean } \pm \text { SD } \\
t \text {-Test } \\
F \text {-test }\end{array}$ & \multicolumn{3}{|c|}{$\begin{array}{l}99.56 \pm 0.87 \\
0.32(2.23)^{*} \\
2.90(5.05)^{*}\end{array}$} & \multicolumn{3}{|c|}{$99.69 \pm 0.44$} \\
\hline
\end{tabular}

\begin{tabular}{ccccc}
\hline \multicolumn{5}{c}{ TABLE- 3 } \\
VALIDATION OF THE PROPOSED \\
SPECTROFLUORIMETRIC DETERMINATION OF \\
DULOXETINE HYDROCHLORIDE IN PURE FORM \\
\hline \multicolumn{5}{c}{ Duloxetine hydrochloride } \\
\hline Taken $(\mathrm{ng} / \mathrm{mL})$ & $\begin{array}{c}\text { Found } \\
(\mathrm{ng} / \mathrm{mL})\end{array}$ & Recovery $(\%)$ & $\begin{array}{c}\text { RSD } \\
(\%)\end{array}$ & $\begin{array}{c}\text { Error* } \\
(\%)\end{array}$ \\
\hline Intra-day precision & & & \\
5 & 4.93 & $98.6 \pm 0.11$ & 0.11 & 0.06 \\
20 & 19.95 & $99.75 \pm 0.08$ & 0.08 & 0.04 \\
70 & 69.85 & $99.78 \pm 0.22$ & 0.22 & 0.13 \\
\hline Inter-day precision & & & & \\
5 & 5.0 & $100.00 \pm 0.07$ & 0.07 & 0.04 \\
20 & 19.93 & $99.65 \pm 0.11$ & 0.11 & 0.06 \\
70 & 69.98 & $99.97 \pm 0.14$ & 0.14 & 0.08 \\
\hline$* \%$ Error $=\mathrm{SD} / \sqrt{ } \mathrm{n}$ & & & & \\
\hline
\end{tabular}

Robustness of the method: The robustness was investigated by changing the experimental conditions, such as the $\mathrm{pH} 9.9 \pm 0.2$, the change in the volume of CTAB, $1 \pm 0.5$ $\mathrm{mL}$. These minor changes that may take place during the experimental operation did not affect the fluorescence intensity.

Results of stability studies: The following degradation behaviours of duloxetine hydrochloride samples were suggested during the forced degradation stress testing under different conditions.

Acid induced degradation: As already reported ${ }^{10}$, the effect of acid degradation was performed using $10 \mathrm{~mL}$ of 0.5 $\mathrm{mol} / \mathrm{L}$ of hydrochloric acid at room temperature for $4 \mathrm{~h}$ and by analogue we studied the rate of degradation in hydrochloric acid and it was found faster as compared with that in alkali. It was found that $15.7 \%$ of the drug solution was degraded.

Alkaline induced degradation: The degradation for duloxetine hydrochloride under alkali was slower than in acidic condition. It was found that by using $10 \mathrm{~mL}$ of $2 \mathrm{~mol} /$ $\mathrm{L}$ sodium hydroxide at room temperature for $8 \mathrm{~h}$ the degradation was so slow and around $8 \%$ of the drug was degraded.

Hydrogen peroxide induced degradation: The effect of oxidative induced degradation of hydrogen peroxide was studied. It was found that treating the drug with $10 \mathrm{~mL}$ of $30 \% \mathrm{H}_{2} \mathrm{O}_{2}$ (v/v) at room temperature, according to the procedure described above, $9.5 \%$ of the drug was degraded.

Thermal-degradation: The effect of heat on the stability of duloxetine hydrochloride was studied. It was observed that about $6.5 \%$ of the drug was degraded even after exposure of the drug to $70{ }^{\circ} \mathrm{C}$ in a water bath for $5 \mathrm{~h}$.

\section{Conclusion}

The proposed micelles enhanced spectrofluorimetric method for determination of duloxetine hydrochloride was developed and validated for precision, specificity and accuracy. The advantage of the proposed method is more sensitive, simple, more accurate and less tedious than chromatographic procedures. On the bases of accuracy and range sample concentrations, the proposed method was successfully applied for the determination of duloxetine hydrochloride in bulk drug and in its pharmaceutical dosage form. 


\section{ACKNOWLEDGEMENTS}

The authors extended their appreciation to the Deanship of Scientific Research at King Saud University for funding the work through the research group project No. RGP-VPP062.

\section{REFERENCES}

1. J.O. Maryadele, Editor, The Merck Index, Whitehouse Station, U.J. Merck Co. Inc.; edn 14, p. 3465 (2006).

2. L. Mirhral, Drug Today, Lorina Publications, Delhi, India, vol. 1, p. 489 (2006).

3. L.L. Brunton, K.S. Parker and J.S. Lazo, Goodman and Gillman's, The Pharmacological Basis of Therapeutics, McGraw Hill Publishing, London, edn 11, 436 (2005).

4. V.R. Sinha, K.R. Anamika and J.R. Bhinge, J. Chromatogr. Sci., 47, 583 (2009)

5. N.V. Raman, K.A. Harikrishna, A.V.S. Prasad, K.R. Reddy and K. Ramakrishna, J. Pharm. Biomed. Anal., 51, 994 (2010).

6. D.D. Rao, S.S. Sait, A.M. Reddy, D. Chakole, Y.R. Reddy and K. Mukkaint, J. Chromatogr. Sci., 48, 819 (2010).

7. S.P. Senthamil, K.V. Gowda, U. Mandal, W.D. Sam Solom and T.K. Pal, J. Chromatogr. B, 858, 269 (2007).
8. N. Ma, B.K. Zhang, H.D. Li, B.N. Chen, P. Xu, F. Wang, R.H. Zhu and Y.G. Zfu, Clin. Chim. Acta, 380, 100 (2007).

9. K.S. Darlene, D.M.C. Juli, K. Fenqjiun and P.K. Mary, J. Chromatogr. B, 852, 582 (2007).

10. S.S. Dhaneshwar, P. Deshpande, M. Patil, G. Vadnerkar and S.R. Dhaneshwar, Indian J. Pharm. Sci., 70, 233 (2008).

11. M.M. Kamila, N. Mondal and L.K. Ghosh, Die Pharmazie, 62, 414 (2006).

12. A. Musenga, M. Amore, R. Mandrioli, E. Kenndler, L. Martino and M.A. Raggi, J. Chromatogr. B, 877, 1126 (2009).

13. N.A. Alarfaj, A.A. Reda and E.T.F. Maha, Chem. Cent. J., 6, 1 (2012).

14. S.L. Prabu, S. Shahnawaz, C.K. Dinesh and A. Shirwaikar, Indian J. Pharm. Sci., 70, 502 (2008).

15. ICH Harmonize Guideline, Validation of Analytical Procedure: Text and Methodology, Q2 (R1), Current Step 4 Version, Parent Guidelines Dated 27 October (1994), Complementary Guidelines on Methodology Dated 6 November (1996), Incorporated in November (2005).

16. W.L. Hinze, H.N. Singh, Y. Baba and N.G. Harvey, Trends Anal. Chem., 3, 193 (1984)

17. A. Patist, V. Chhabra, R. Pagidipati, R. Shah and D.O. Shah, Langmuir, 13, 432 (1997)

18. D.A. Skoog, F.J. Holler and S.R. Crouch, Fundamentals of Analytical Chemistry, Saunders College Publishing, Philadelphia, edn 8, p. 1003 (2004). 